\title{
Problem kategorii decyzji w kontekście naturalistycznego paradygmatu nauk społecznych
}

\section{The Problem of the Category of Decisions in the Context of the}

\section{Naturalistic Paradigm of Social Sciences}

\begin{abstract}
The paper presents the thesis that a decision understood as an act of choice could be explained within the framework of the theory of control, which implicates real human autonomy. A decision in this perspective is not a type of phenomenon detached from the causal structure of the world, nor a kind of handy theoretical structure in explaining behaviour, but a functional aspect of the mind compatible with the naturalistic view of the world, including the humanities. Within such an explanatory structure, we can place decisions as part of the control structures that function alongside causality structures and are a necessary component of any autonomous system. Moreover, if the mind acts as a semantic engine, we can outline the direction of research within which semantics (language, cultural meanings, and content) can be interpreted as the basis for choices (decisions) made within the cultural context.
\end{abstract}

Keywords: naturalism, decisions, free choice, rationality, determinism, social sciences

Natura relacji zachodzących pomiędzy umysłem a decyzją rozumianą jako akt wyboru stanowi podstawę architektury poznawczej, określającą zachowania jako przedmiot badań w naukach społecznych. Z punktu widzenia metodologii redukcjonistycznej (respektującego co do zasady porządek eksplanacji w nauce) oba fenomeny powinny znaleźć swoje wyjaśnienie w ramach nauk biologicznych (podstawa współczesnego naturalizmu), a w szczególności w ramach psychologii ewolucyjnej. Akt wyboru z założenia nie jest niczym innym jak rodzajem aktu poznawczego, stąd przyjmujemy, że jest on jednym $\mathrm{z}$ aspektów umysłu w jego funkcjonalnej interpretacji. Szczególny status, jaki zwykle mu 
przypisujemy, wiąże się z dwoma kontekstami lub też ramami interpretacyjnymi. Pierwszy z nich związany jest $\mathrm{z}$ humanistyką i jej zakorzenieniem $\mathrm{w}$ kulturowych (samo)-interpretacjach człowieka, w tym w filozoficznych koncepcjach antropologicznych ${ }^{1}$. Drugi związany jest $\mathrm{z}$ różnymi praktykami społecznymi, dla których kategoria wyboru (w domyśle wolnego i/lub racjonalnego) jest elementem konstytutywnym. Dotyczy to takich praktyk jak prawo (stanowienie, egzekucja czy podleganie prawu), ale też ekonomii (racjonalne wybory) i polityki (wolny i racjonalnie głosujący obywatel).

Powstaje zatem pytanie o miejsce decyzji, a precyzyjniej rzecz ujmując o miejsce znaczenia, jakie z nią wiążemy, czyli aktu (wolnego) wyboru, w strukturze eksplanacyjnej naturalistycznego paradygmatu nauk społecznych. Zakładając, że modele eksplanacyjne w nauce reprezentują związki zachodzące pomiędzy zjawiskami, które charakteryzujemy za pomocą kategorii przyczynowości, uogólnianej często do poziomu praw, pierwszym problemem, z jakim musimy się zmierzyć, jest problem uniwersalnego determinizmu. Paradygmat myślenia o determinizmie w nauce jest przedstawiany za pomocą eksperymentu myślowego Laplace’a, w którym hipotetyczny demon jest w stanie przewidzieć kolejne stany wszechświata na podstawie informacji o parametrach każdej cząstki (Carroll, 2017, rozdz. 4). W tym sposobie widzenia determinizmu, w kontekście naszego problemu, ważny jest aspekt wiedzy reprezentowany przez demona (kategoria punktu widzenia jest istotna dla prezentowanej tu koncepcji wyboru) i jego zdolność przewidywania (predykcji każdego z kolejnych stanów). Na pytanie, skąd wiemy, że świat jest rodzajem zdeterminowanej struktury, możemy w tym wypadku odpowiedzieć, że uzasadnieniem takiej tezy jest fakt możliwości przewidywania przyszłości na podstawie wiedzy o aktualnym stanie systemu. Determinizm jest zatem prawdziwy, ponieważ możemy w różny sposób testować naszą wiedzę o zachowaniach świata, przewidując (obliczając) wynik testu.

Możemy też w odruchu optymizmu poznawczego założyć, że demon jest w stanie przewidzieć drugi podstawowy proces obserwowany w świecie, czyli proces powstania i ewolucji życia. Jeszcze większym przejawem optymizmu byłoby założenie, że przewidział pojawienie się zjawisk kulturowych, które zwykle łączymy z wyższymi funkcjami umysłu, oraz ich ewolucję do poziomu nauki. Pozostawiamy tu na boku zmianę rozumienia natury zjawisk fizycznych, która

\footnotetext{
Zob. Arendt, 1996 (praca zawiera krytyczny przegląd teorii woli) oraz Żyro, 2008 (problem woli w teoriach polityki). Wola, podobnie jak rozum, stanowi dość pochopne urzeczowienie aspektów czynnościowych mózgu. Pochopne w tym sensie, że prowadzące do niekończących się poszukiwań istoty woli czy rozumu w sytuacji, gdy mamy do czynienia z procesami realizowanymi przez układ nerwowy. Ich natura, czy po prostu charakterystyka, może nadal nam umykać, ale założenie, że mamy do czynienia z procesami, jest pierwszym krokiem zrywającym z metaforą rozumu jako rozkazodawcy woli lub też umysłu rozpatrywanego poprzez metaforę pudełka albo zbiornika, który zawiera w sobie w sposób bliżej niesprecyzowane kompetencje lub treści, na przykład prawa logiki czy etyki. Zob. Ainslie, 2001.
} 
miała miejsce po eksperymentach Laplace’a, ponieważ w domenach, na które wskazaliśmy powyżej, determinizm tak interpretowany nadal pozostaje tylko założeniem. To znaczy, że nie dysponujemy modelem, który możliwość takiej wiedzy mógłby uprawdopodobnić. Na ogólnym poziomie mamy tu do czynienia ze zjawiskami, które określa się mianem historycznych, czyli zachodzących z udziałem czynników czysto losowych. Ponadto wraz z organizmami dochodzi do pojawienia się zupełnie odmiennego typu interakcji, zachodzącego zarówno wewnątrz nich (subiektywny punkt widzenia, który pojawia się już na etapie ruchu kierunkowego organizmu), jak i na zewnątrz, czyli interakcji ze środowiskiem, które nie ma już charakteru czysto fizycznego (Godfrey-Smith, 2019, s. 101-110). Pojawiły się, nawiązując tu do wcześniejszego terminu, odmienne punkty widzenia zainteresowane własnym przetrwaniem, które generalnie realizują tę strategię na podstawie procesów przetwarzania informacji. Świat stał się złożony w sposób nieredukowany do czysto fizycznych parametrów, ponieważ pojawiły się w nim różne perspektywy, wynikające $z$ różnych punktów widzenia i kompetencji poznawczych (od struktur sensorycznych po możliwości reprezentowania własnego środowiska). Co więcej, charakter interakcji pomiędzy organizmami, pod wieloma względami antagonistyczny, sprawił, że ukrywanie własnego punktu widzenia stało się jedną z podstawowych strategii przetrwania (Hippel, Trivers, 2011, s. 1-56).

Przyjęcie perspektywy informacji pozwala na analizę zachowań, która stanowi rozszerzenie wąsko pojętego fizykalizmu, nawet jeśli jest to tylko rozszerzenie na poziomie modelu obserwowalnych fenomenów. Na podstawowym poziomie mówimy po prostu o innym sposobie organizacji elementów świata, które w analizie funkcjonalnej przekładają się na inne zachowania. Organizacja i informacja pozostają w stosunku do siebie w dość intrygującym związku, który interpretujemy najczęściej za pomocą szerokiego pojęcia struktury lub wzoru. Trudno by nam było na przykład mówić o nieuporzadkowanej informacji, stąd pojęcie chaosu rodzi tyle kontrowersji ${ }^{2}$. Z perspektywy doświadczenia możemy natomiast obserwować odmienne zachowania struktur, których odmienność jest rezultatem innej ich organizacji. Taką obserwowalną różnicą zachowania jest różnica pomiędzy zjeżdżającym ze stoku narciarzem a toczącym się po tym samym stoku głazem (Dennett, 2020, s. 148-164). Jest to różnica, która zachodzi $w$ ramach tego samego systemu fizycznego. W tym wypadku inny sposób organizacji przekłada się na inny poziom kontroli zdarzenia. Przy czym w przypadku głazu jest zupełnie pozbawione sensu mówienie o kontroli, ponieważ jego zachowanie jest w pełni uwarunkowane przez właściwości fizyczne czy też prawa fizyki, natomiast narciarz jest typem systemu intencjonalnego, który wyznacza sobie określone zadanie i próbuje je realizować. Obserwujemy zatem

Na temat genezy nowego paradygmatu myślenia o świecie, który wyłonił się jako konsekwencja badań nad systemami złożonymi, zob. Gleick, 1996. 
sytuację, w której zarówno głaz, jak i narciarz podlegają przyczynowości fizycznej, ale narciarz - w przeciwieństwie do głazu - kontroluje przebieg spadania ${ }^{3}$. Może oczywiście popełnić błąd, którego skutkiem będzie utrata kontroli. Głaz natomiast nie popełnia błędu w żadnej interpretacji (może $\mathrm{z}$ wyjątkiem jakiejś wersji teleologicznej fizyki Arystotelesa) i nie jest to trywialna okoliczność w zestawieniu z organizmami oraz systemami społecznymi.

Minimalne wymagania, które musi spełniać system, abyśmy mogli mówić o pojawieniu się zjawiska kontroli, to pętla sprzężenia zwrotnego i wewnętrzny układ przetwarzania informacji. Jeśli uogólniamy mechanizm sprzężenia zwrotnego i rozpatrujemy go jako proces przebiegający w określonym czasie, to zbliżamy się do takiego stanu systemu, w którym możemy mówić o pojawieniu się wewnętrznego agenta, rozumianego jako przybliżone centrum zarządzające systemem. Funkcja kontrolna centrum może być spełniana na różnym poziomie i w różnym zakresie, tak jak w przypadku świadomej refleksji w stosunku do nieświadomego procesu umysłowego (Kahneman, 2012, s. 31 i n.). Podobnie jak $\mathrm{w}$ przypadku rozpatrywanego przykładu narciarza, jego autonomia, wynikająca z posiadanej kontroli nad zjazdem ze stoku, jest również funkcją nabytych wcześniej umiejętności, czyli wynikiem określonego procesu uczenia się, w trakcie którego popełniał błędy, które były dla niego rodzajem informacji zwrotnej. System uczy się poprzez błędy i tylko wtedy, kiedy popełni błąd krytyczny, może nie mieć już szansy go skorygować. Organizmy wykazują się olbrzymią elastycznością pod tym względem, a jeszcze większą elastyczność w procesie uczenia się wykazują ludzkie mózgi czy szerzej - układy nerwowe (Ramachandran, 2012, s. 47 i n.).

Gdybyśmy na poziomie tej prostej idealizacji działania systemu zadali pytanie o to, kto lub co podejmuje decyzje czy dokonuje wyboru, to moglibyśmy udzielić odpowiedzi w dwojaki sposób. W pierwszej wersji odpowiedź brzmi: decyzje podejmuje cały system jako pewien dynamiczny układ. W drugiej wersji odpowiedź mogłaby wskazać na taki topos w ramach tego systemu, który monitoruje działanie całości systemu (poręczna parafraza: uświadamia sobie stan całości systemu). Spójrzmy na ten problem poprzez pryzmat eksperymentu Libeta i jego replikacji ${ }^{4}$. Eksperyment miał dowieść lub też obalić hipotezę o istnieniu wolnej woli jako fenomenu, który pojawia się na poziomie naszej świadomości. Zwróćmy przy tej okazji uwagę na fakt, że o ile nikt nie ma wątpliwości co do istnienia takiej kategorii, z różnymi jej kulturowymi i filozoficznymi konotacjami, o tyle istnienie samego zjawiska, jako fenomenu, który każdy z nas jest sobie w stanie jasno i wyraźnie przedstawić (w duchu kartezjańsko-husserlowskim),

Rozwinięcie dyskusji, włącznie z możliwymi konsekwencjami dla rozumienia odpowiedzialności społecznej, prawnej i politycznej, w: Dennett, Caruso, 2021.

4 Dokładny opis eksperymentu Libeta można znaleźć w: Majchrowicz, Doboszewski, Placek, 2016. 
jest już mocno wątpliwe ${ }^{5}$. Ta dygresja jest istotna ze względu na sposób operacjonalizacji problemu i kategorii wolnej woli w ramach samego eksperymentu. O jego wyniku miał bowiem przesądzić poziom korelacji pomiędzy ruchem ręką, uświadomieniem sobie decyzji o wykonaniu tegoż gestu i zarejestrowaną aktywnością obwodu neuronów w mózgu. Brak synchronizacji, polegający na wcześniejszej aktywności mózgu w stosunku do uświadomienia sobie decyzji o wykonaniu określonego ruchu, miałby przesądzać o braku wolnej woli u człowieka. Takie podejrzenie, o istnieniu w człowieku różnych podsystemów, wyrażał w charakterystyczny dla siebie sposób myślenia, czyli za pomocą metafory, już Platon (Platon, 1997, s. 44 i n.). Warto przywołać ten motyw w dyskusji nad wolnością działania, ponieważ intuicja Platona zdaje się lepiej oddawać problem tego, czy w odniesieniu do ludzkiego umysłu możemy mówić o jakimś jednoznacznym centrum.

Wróćmy jednak do wyników eksperymentu i spójrzmy na niego z punktu widzenia wcześniej postawionego problemu, czyli podejmowania decyzji przez cały system lub/i przez określone centrum systemu. Parafrazując problem w jeszcze inny sposób - czy informacja o podjęciu decyzji (poziom świadomości), opóźniona w stosunku do wyboru dokonanego przez mózg, może stanowić argument przeciwko wolności systemu, jakim jest człowiek, jeśli umysł i mózg traktujemy jako funkcjonalną całość? Otóż wynik eksperymentu nie stanowi żadnego wyzwania dla tak rozumianego aktu wyboru, ponieważ sam wybór jest tylko abstrakcyjnym punktem, który jesteśmy w stanie świadomie wyznaczyć w sytuacji, gdy system dokonuje wyborów w ramach złożonego procesu. Zwróćmy uwagę na fakt, że tak zwane posiadanie wolnej woli nie jest nawet dobrym przybliżeniem tego, co zachodzi w ramach złożonego systemu. Rodzi zresztą podobne problemy jak problem homunkulusa w teorii świadomości, czyli prowadzi do regresu, w którym funkcjonowanie homunkulusa jest wyjaśniane jeszcze mniejszym homunkulusem w homunkulusie. Jeśli wolna wola czy wolny wybór nie jest niczym związany, poza wolną wolą, to może być ona wyjaśniona tylko poprzez wolną wolę.

W pewnym istotnym sensie rozstrzyganie tych problemów jest kwestią przyjmowanej perspektywy. Perspektywa w tym rozumieniu nie jest jednak dowolnym punktem widzenia, ale wskazaniem na fakt, że różne cechy czy własności świata mają swoje znaczenie jedynie w ramach określonych relacji. Tak jak organizmów nie rozpatrujemy w ramach biologii jako systemów fizycznych (którymi oczywiście są), ale jako elementy ekosystemu, w ramach którego wchodzą w relacje z innymi jego elementami (organizmami pozostającymi w różnych

Jedną z najtrafniejszych krytyk wolnej woli zawdzięczamy Fryderykowi Nietzschemu (zob. Colli, 1994), ale nawet w tradycji anglosaskiej kategoryzacja woli jako wolnej nie była powszechna (J. Locke i D. Hume). Arystoteles posługiwał się dla odmiany terminem proairesis, przemyślanego wyboru. Podstawowy problem z „wolną wolą" miał natomiast Paweł z Tarsu ze względu na liczne niepowodzenia w podporządkowaniu woli zmysłów i emocji (zob. Arendt, 1996). 
relacjach pokrewieństwa przedstawianych za pomocą drzewa życia), tak też i na sam problem kontroli, autonomii i wolności powinniśmy patrzeć $\mathrm{w}$ ramach określonych relacji. Możemy zatem mieć wątpliwości lub też nie wiedzieć, czym jest centrum ludzkiego umysłu (w standardowej interpretacji jest to samoświadomość), ale większość z tych wątpliwości rozwieje się jak poranna mgła, jeśli indywiduum umieścimy w kontekście społecznym, które jest podstawowym polem interakcji pomiędzy ludźmi.

Przywoływałem wcześniej eksperyment myślowy Laplace’a z demonem obliczającym przyszłe stany świata, rozumianym jako pewien punkt widzenia na rzeczywistość. Zróbmy użytek z punktu widzenia jako kategorii epistemologicznej i perspektywy, jaka się wraz z tym eksperymentem pojawia. Każdy uczestnik interakcji społecznych jest typem niedoskonałego demona (o ograniczonych mocach obliczeniowych), znajdującym się w sytuacji dużo trudniejszej pod względem epistemicznym niż demon Laplace’a. Trudniejszej też w rozumieniu relatywnym, czyli wtedy, gdy podobnie jak on próbuje obliczyć przyszłe stany świata, a w tym wypadku zachowania innych podmiotów i ich skutki w stosunku do siebie. W przeciwieństwie do oryginału demon społeczny nie działa w sposób bezinteresowny, czyli tylko ze względów poznawczych. Próbuje natomiast przewidywać przyszłość po to, aby kontrolować zachowania innych w sposób, który jemu samemu przyniósłby największe korzyści. Pomijając złożoność i paradoksy wynikające z próby instrumentalizacji zachowań innych w stosunku do własnych celów, zwróćmy uwagę na to, że w tej grze stawką jest kontrola nad innymi. $Z$ tego punktu widzenia to dążenie niczym się nie różni od próby narciarza zjeżdżającego ze stoku w sposób optymalny, jak również nie zmienia się podstawowa zależność polegająca na efektywnym pozyskiwaniu i przetwarzaniu informacji z istotnego dla niego środowiska.

Problem epistemiczny, który pojawia się w ramach tej perspektywy, to również problem każdego badacza systemów społecznych. Podobnie jak nasz demon, musi się on zmierzyć z cechą systemów społecznych, którą określamy za pomocą kategorii nieprzejrzystości (to jedna z cech złożoności). Czyli dostęp do informacji, które byłyby wartościowe z punktu widzenia przewidywania zachowań, jest zawsze utrudniony, ponieważ są one zawarte w systemach w relacji do nas izolowanych. Zamiast czystego pola obserwacji pojawia się tutaj język jako podstawowy kanał komunikacyjny z całą swoją złożonością syntaktyczną i semantyczną. Pominiemy tutaj problem braku obowiązującego zestawu przyjętych wzorów parametryzacji zachowań, co stanowi istotną różnicę w stosunku do systemów fizycznych. Innymi słowy, zbiór koniecznych i wystarczających czynników warunkujących zachowanie człowieka pozostaje nadal otwarty. Stąd też rozróżnienie na warunki konieczne i wystarczające w praktyce badawczej staje się dużo mniej precyzyjne, czyli rozmyte.

Tak przedstawia się podstawowy problem badacza i demona społecznego, z którym muszą się oni uporać, aby zachować kontrolę $\mathrm{w}$ stosunku do 
interesującej ich domeny. Istnieje też jednak druga strona tej sytuacji, którą możemy sprowadzić do perspektywy braku informacji, braku wiedzy (niepewności wiedzy), a w związku z tym braku możliwości kontroli. Jeśli rozpatrywalibyśmy tę sytuację poprzez teoretyczne ekstremum, to moglibyśmy powiedzieć, że wolny podmiot zachowań to podmiot, o którym pozostałe strony interakcji nie posiadają żadnej informacji i w związku z tym może on działać (dokonywać wyborów) w sposób zupełnie dla nich nieprzewidywalny. Zauważmy, że podobnym, trudnym do przyjęcia czy zrozumienia ekstremum jest idea wolnej woli jako cechy świata, człowieka, która nie jest niczym innym związana poza samą sobą. Pozostając w ramach naturalistycznego rozumienia rzeczywistości, musimy uznać, że jeśli coś istnieje w tym świecie, choćby na poziomie możliwości, to musi pozostawać w jakichś typach relacji, czyli związkach zależności (niekoniecznie w sekwencyjnie rozumianej przyczynowości). Wpisując akty wyboru (decyzje) w teorię kontroli, która jest podstawą autonomii, oraz w teorię informacji i wiedzy rozumianej jako ten typ informacji, za pomocą którego podmiot (autonomiczny system) może wykonywać określone przez siebie czynności, wpisujemy je w typ relacji, który pojawia się wraz z biologią. To, co tu pomijamy, a co jest istotne na poziomie badań nad sztuczną inteligencją, to istnienie systemów skonstruowanych przez człowieka, które też charakteryzuje zróżnicowany poziom autonomii ${ }^{6}$.

W kontekście świata społecznego funkcjonowanie poza jakąkolwiek kontrolą (świat absolutnie wolnych społecznych demonów) jest z kolei niemożliwe z dwóch zasadniczych powodów. Pierwszy wynika z biologicznych podstaw każdego społeczeństwa (system wzajemnie realizowanych potrzeb), a drugi z konieczności współpracy zgodnie z określonymi zasadami. Stąd każdy system społeczny w toku ewolucji wytwarza systemy kontroli (Gamble, Gowlett, Dunbar, 2017, s. 279 i n.). Charakter relacji społecznych jest jednak odmienny od zależności czysto fizycznych (z nimi zmaga się narciarz) i jest również odmienny od zależności czysto biologicznych (odżywianie i reprodukcja gatunkowa). Podstawową różnicą jest poziom zdeterminowania, czyli tych zależności w świecie, które są poza zakresem kontroli. Z punktu widzenia teorii informacji jego funkcjonowanie zależy od typu kanałów komunikacyjnych i typu informacji, która rozstrzyga o organizacji zachowań. Ta zależność pozostaje funkcją możliwości poznawczych każdego organizmu, wynikających z architektury układu nerwowego. Gatunki społeczne podzielają wiele cech wspólnych, wynikających z faktu organizacji mnogości grupy (metafory mające swoje źródło w organizacji mrówek czy pszczół nadal mają swoich zwolenników w teorii społecznej), ale gatunek ludzki różni się od nich radykalnie właśnie pod względem poznawczym. Posiada różne reprezentacje świata i samego siebie, i to jest między innymi źródłem problemu wolnej woli. Ale też fakt dysponowania taką, a nie inną architekturą

Przypomnienie historii idei cybernetyki i stan współczesny całej dyscypliny: Brockman (ed.), 2019. 
poznawczą przenosi człowieka w zupełnie inny wymiar zależności i prób uzyskania kontroli nad swoim życiem. Dzieje się tak z powodu występowania na poziomie języka i teorii reprezentacji czasu, w wyniku czego problem kontroli decyzji staje się dużo bardziej złożony, ponieważ stanowi próbę opanowania własnego losu i nabiera charakteru egzystencjalnego. W zasadzie wszyscy się zgadzamy, że człowieka wyróżnia zdolność do planowania, na którym to przekonaniu zbudowano całą dyscyplinę w naukach społecznych. Z punktu widzenia naszej analizy każde planowanie jest rodzajem determinowania zachowań poprzez przyszłość w sposób kontrolowany, czyli jest to rodzaj sprzężenia zwrotnego z nieistniejącą przyszłością ${ }^{7}$. Celowościową teorię działania zastąpiliśmy teorią planowania w przekonaniu, że nauka pozwala na przewidywanie przyszłości (tutaj wraca nam demon Laplace’a w pełnej postaci) lub przynajmniej może przewidywać skutki zachowań w kolejnych rzędach konsekwencji ${ }^{8}$. Decyzje w tym kontekście zostały zredukowane do aktów wyboru pomiędzy mniej lub bardziej ryzykownymi zachowaniami, w tym obarczonymi niepewnością (Bernstein, 2020). Pomiędzy planowaniem i realizacją planu a przewidywaniem przyszłości istnieje jednak różnica, wynikająca $\mathrm{z}$ faktu, że w pierwszym wypadku próbujemy przewidzieć losy własnego projektu w ramach przyszłych, możliwych stanów świata. W tym sposobie myślenia odnajdujemy zarówno przedefiniowaną celowość, jak i możemy zauważyć, że demon Laplace’a przeobraża się w twórcę świata, co jest zadaniem dużo bardziej wymagającym ${ }^{9}$. W języku nowoczesnym twórca zamienia się w inżyniera przyszłych światów, ale idea, że możemy budować użyteczne dla siebie systemy, wykorzystując wiedzę o deterministycznych układach świata, pozostała ta sama pomimo paradoksalnych konsekwencji w odniesieniu do natury tak rozumianego inżyniera.

$7 \quad$ Zaznaczmy tutaj, że w fizycznym obrazie świata brak jest różnicy pomiędzy wymiarami czasu znanymi z doświadczenia potocznego, a problem tak zwanej strzałki czasu wiązany jest ze zjawiskiem entropii. Świadomość ze swoją strukturą czasową przynależy do doświadczenia subiektywnego. Por. Carroll, 2017; Dolev, Roubach (eds.), 2016.

8 Zauważmy, że pomiędzy światem naturalnym a kulturą w momencie pojawienia się nauki nowożytnej nastąpiło pęknięcie czy też luka eksplanacyjna, związana z przyjęciem w przyrodoznawstwie modelu determinizmu, który odrzucił przyczynowość celową i teleologiczny obraz świata (zob. Weinberg, 2016). Czysty determinizm w rozumieniu modelu fizycznego mechanizmu wydał się być niezdolny do wyjaśnienia umysłu wraz z celowym działaniem, które w ramach pewnego ideału kulturowego było determinowane przez rozum. W naukach społecznych, które próbowały odnaleźć się w nowym obrazie świata, pojawił się behawioryzm wraz ze swoim czysto przyczynowym modelem zachowań, który pozbawił umysł znaczenia, oraz psychoanaliza, która z kolei pozbawiła umysł rozumu. W radykalnie socjologicznym ujęciu człowieka przez Marksa stał się on funkcją relacji społecznych i podlegał ewolucji wraz z nimi w całym zakresie swoich zachowań.

9 Podobieństwo pomiędzy wzorami podejmowania decyzji a klasycznymi problemami posługującej się logiką optymalizacji (świat najlepszy z możliwych lub też najlepszy z najgorszych) analizował Merton, 1936, s. 894-904. 
Procesy decyzyjne są stopniowalne, podobnie jak systemy kontroli na różnych poziomach i skalach, czyli możemy je analizować zarówno na poziomie środowiska naturalnego, jak i na poziomie zjawisk kulturowych. Możemy również pokusić się o doprecyzowanie wolności wyboru, wprowadzając do naszej analizy pojęcie opcji (możliwej do realizacji ścieżki w danej sytuacji), których liczba pozwalałaby nam skalować kategorię wolności wyboru (Schwartz, 2020). Taki punkt widzenia możemy analizować $\mathrm{w}$ relacji do zakładanego centrum, czyli w przypadku człowieka w relacji do refleksyjnego ja, dysponującego użyteczną dla niego wiedzą. Użyteczność wiedzy jest jednak relatywna w stosunku do zakładanych celów i poza określonym kontekstem jest pustą kategorią. Racjonalność utylitaryzmu była kwestionowana wielokrotnie ze względu na niemożność sformułowania w ramach tego stanowiska sensownych celów zachowań. Kategorie sensu i korzyści pozostają w stosunku do siebie w zaskakującej relacji, w której to, co korzystne, bywa sensowne, a to, co sensowne, bywa korzystne, ale nie jest to żadną ogólną regułą. Korzyść możemy łatwo zinterpretować w kategoriach ilościowych, a stąd łatwo ją przełożyć na instytucję pieniądza, który stał się podstawową miarą sensownych zachowań społecznych (Simmel, 1997, s. 98 i n.). Człowiek racjonalny, interpretowany w ramach tej instytucji, to ktoś, kto chce posiadać więcej pieniędzy (lub też więcej czegokolwiek), a ilość posiadanego pieniądza rozstrzyga o pozycji społecznej oraz o byciu racjonalnym. Prostota tej idei dobrze służy jej popularyzacji, ale jest tylko efektem zastosowania metody redukcyjnej, która zarówno ludzkie emocje, jak i zjawiska kulturowe sprowadza do jednego wymiaru. W tym wypadku mamy do czynienia z redukcją człowieka do prostej emocji, czyli chciwości, która łatwo ulega skalowaniu. Zgodnie z jej logiką więcej zawsze oznacza lepiej i jest to twierdzenie, które łatwo uzasadnić czy zracjonalizować, odwołując się do miar matematycznych, choć uprawdopodobnia ją w naszych oczach siła samej emocji ${ }^{10}$.

Ekonomiczność zachowań jest jedną z podstawowych cech, które możemy zaobserwować w świecie natury. Podobnie jak zjawisko wymiany, będące podstawą zachowań ekonomicznych. Jeśli to drugie stanowi jakiś rodzaj społecznego układu nerwowego (ze względu na informację zawartą w systemie), to i tak jest jednym $\mathrm{z}$ analitycznie wyizolowanych układów, które możemy analizować w kontekście kultury. Jedną z możliwych strategii przedstawienia złożoności kulturowej jest ponowne przyjęcie perspektywy demona społecznego, tym razem nie w postaci maszyny obliczeniowej, ale w postaci quasi-silnika semantycznego, który $\mathrm{w}$ tradycyjnej terminologii moglibyśmy określić mianem wyróżnionego interpretatora (poszukiwacza sensu w tradycyjnej humanistyce). Powyższa sytuacja czerpie swoje znaczenie $\mathrm{z}$ dwóch rozróżnien istotnych dla teorii informacji i dla współczesnej teorii umysłu. Pierwsze to rozróżnienie na informację

10 Fakt odróżnienia w ekonomii użyteczności i ilości pieniądza niekoniecznie przekłada się na bardziej złożony poziom racjonalności zachowań. 
w rozumieniu fizycznym (charakteryzowana ilościowo) i semantycznym, a drugie to rozróżnienie na mózg/umysł rozumiany jako silnik obliczeniowy (metafora komputera w badaniach nad mózgiem) i mózg/umysł spełniający funkcję silnika semantycznego (Woleński, 1997, s. 59-64; Hetmański, 2013, s. 109 i n.; Haugeland, 1981). Powyższe podziały możemy również analizować z perspektywy klasycznego podziału na syntaktykę i semantykę w języku. Dla nas istotny jest fakt, że zawartość informacyjna semantyki jest bogatsza od ujęcia czysto formalnego zjawiska informacji. Koresponduje to $\mathrm{z}$ faktem znanym $\mathrm{z}$ teorii informacji, że pomimo iż semantyczny interpretator pojawił się już w pracy Claude’a E. Shannona i Warrena Weavera, to jego rola w procesie komunikowania pozostała niewyjaśniona.

Świat ukształtowany na poziomie semantycznego demona jest zatem światem odmiennym od jego poprzednich wcieleń, czyli fizycznego i społecznego, choć oczywiście nie jest innym światem rozłącznym pod względem ontologicznym. Przynajmniej $\mathrm{w}$ ramach naturalistycznie interpretowanych nauk społecznych nie możemy przyjmować takiego założenia. Natomiast semantyki świata(-ów) są zróżnicowane na wiele sposobów, od poziomu percepcji i znaczenia (doświadczanie kolorów czy dźwięków) po znaczenia reprezentowane przez archetypy kulturowe (rytuały, instytucje). Instytucja pieniądza, która na poziomie podstawowym pełni podobną funkcje w systemach wymiany, na poziomie kulturowych wag i znaczeń może być zupełnie inaczej interpretowana. Za prawdziwy pieniądz może być na przykład uznawana tylko waluta danego kraju, ponieważ w oczach swoich użytkowników jest zjawiskiem naturalnym. Podobnie jest $\mathrm{z}$ funkcją pieniądza w konstruowaniu społecznego prestiżu. W odniesieniu do języka, ze względu na rozległość tematu, zaznaczmy tylko na marginesie, że rozwinięcie tej problematyki możemy znaleźć w pracach o niezdeterminowaniu przekładu, nieprzejrzystości znaczenia czy niewspółmierności pojęć stosowanych $\mathrm{w}$ ramach różnych teorii naukowych ${ }^{11}$. Na poziomie analiz społeczno-kulturowych problematykę powyższą możemy znaleźć w sporach o uniwersalność lub też relatywizm kulturowy, związany z podstawowym z punktu widzenia decyzji pojęciem racjonalności ${ }^{12}$.

$\mathrm{Z}$ perspektywy demona semantycznego problem wyboru i problem determinizmu, w tym przewidywalności, przedstawiają się w równie złożony sposób. Kultura, rozumiana jako pewien system interpretacji świata i jego uczestników, jest $\mathrm{z}$ punktu widzenia jednostki stanem zastanym i w tym sensie determinującym jego zachowania, $w$ tym podstawowe wymiary jego indywidualnej tożsamości: od języka po system przekonań. Systemy wartości w każdej kulturze

11 Przegląd sporu o rodzaje naturalne można odnaleźć w: Odrowąż-Sypniewska, 2006.

12 Debata wywołana pracami Petera Wincha nad podstawami nauk społecznych zachowuje swoją ważność w kontekście problemu społecznego konstruowania znaczeń bez eksternalistycznego odniesienia, zob. Mokrzycki (red.), 1992. 
określają z kolei możliwy zakres decyzji, motywowany systemem kar i nagród społecznych. Niemniej jednak każdy podmiot zachowuje zakres swobody, który możemy w pewien sposób mierzyć liczbą opcji. Determinizm kulturowy nie jest też tak jednoznaczny, jak determinizm fizyczny, a teoria determinizmu językowego okazała się być dość pochopną interpretacją świata kultury ${ }^{13}$. Pomijam tu złożony problem kauzalnego domknięcia świata na poziomie fizyki, ponieważ i tak nie możemy wykluczyć, że przyszła fizyka zmieni jeszcze nasze rozumienie świata. Kultura interpretowana na tak ogólnym poziomie nie jest jednak podstawową perspektywą podmiotu, ale jednym z jakościowych parametrów, które uwzględnia on, planując własne działania (nawet jeśli podmiot robi to w ramach nieuświadamianych założeń). Swojskość wynikająca z uczestnictwa w tej samej kulturze może być również czynnikiem wprowadzającym w błąd, ponieważ nie likwiduje ona problemu zaufania w podejmowaniu współpracy i związanego z tym ryzyka. Struktury gier społecznych mogą być określone poprzez semantykę (może nawet szerzej - przez semiotykę, w zależności od zakresu tych dyscyplin), ale i tak tworzą strukturę, która rozstrzyga o systemie podległości. W klasycznym ujęcia świata politycznego w postaci ustrojów (systemów instytucjonalnych) dominuje problem znaczenia, czyli definiowania poszczególnych instytucji. Znaczenia jednak nie stanowią żadnego trwałego punktu odniesienia ani nie są rozstrzygające z punktu widzenia systemu podległości, czyli społecznej syntaktyki. Mogą jednak ją okazjonalnie (okazjonalność posiada tu prawdopodobnie systematyczny charakter) kształtować w sposób, którego nie możemy przedstawić na poziomie formalnym. Szczytem wyrafinowania teoretycznego stała się metafora sieci (inspiracją jest niewątpliwie Internet, który rodzi też pokusę, aby interakcje społeczne sprowadzić do częstotliwości połączeń w sieci, czyli rezygnacji z semantyki), ale nie jest jasne, co stanowi mechanizm jej formowania i ewolucji ${ }^{14}$.

Podobnie sprawa przedstawia się, jeśli analizujemy tożsamości indywidualne, które nie pozostają na poziomie znaczeń neutralne (odrębne znaczeniowo) w stosunku do tożsamości społecznych, całej przestrzeni ról i funkcji, w które aktorzy społeczni przebierają się dla podwyższenia własnego statusu. Tożsamość stanowi jeden $\mathrm{z}$ podstawowych wyznaczników decyzji w interakcjach społecznych, w których droga w górę stanowi odpowiednik przyszłego, pożądanego stanu świata. Zawężenie horyzontu poznawczego w ramach społecznego Umweltu jest niezwykłe, ponieważ znaczenie konstruowane społecznie staje się substytutem rzeczywistości. Wiara w konstruowaną społecznie tożsamość nie jest jednak bez znaczenia (według Roberta Travisa jest rzeczą niezbędną, aby uwierzyć

13 Restrykcyjność kultur możemy na przykład analizować z punktu widzenia ścisłości reguł, ale żadna reguła społeczna nie spełnia warunku koniecznego i wystarczającego do zajścia jakiegoś zachowania. Zob. Bicchieri, 2002.

14 Ewolucja kulturowa w ramach naturalizmu stanowi kolejną próbę jego zrozumienia. Zob. Sperber, 1996. 
w kłamstwo, ponieważ jest to sposób na zwiększenie władnej wiarygodności), włącznie $\mathrm{z}$ wiarą $\mathrm{w}$ wolnq wolę, ponieważ subiektywne przekonanie o posiadaniu kontroli nad własnym zachowaniem faktycznie wpływa na to, jak się zachowujemy (Kushnir, Gopnik, Chernyak, Seiver, Wellman, 2015, s. 79-101). Nasze umysły reagują na różnice $\mathrm{w}$ znaczeniach i w ten sposób spełniają swoją funkcję. Czyli analogicznie do sugestii wyrażonej przez Daniela C. Dennetta, że status wolnej woli jest analogiczny do statusu kolorów i ich doświadczenia, możemy przyjąć, że jeśli kolory wpływają na nasze zachowanie, to czyni to również doświadczenie (wyobrażenie) bycia wolnym. Trudniejszą do realizacji ścieżką, która $\mathrm{w}$ ramach kultury może być różnie wartościowania, jest proces uczenia się, rozumiany również jako proces zyskiwania kontroli nad własnym życiem. Jest on jednak uwarunkowany społecznie i kulturowo, czyli istnieje na poziomie możliwości funkcjonalnych naszego umysłu, ale jego realizacja jest warunkowana przez kulturę.

Z punktu widzenia wolności indywidualnej, interpretowanej jako niezależność, najistotniejsza jest niedookreśloność zależności, zarówno w systemie społecznym, jak i kulturowym, a w konsekwencji możliwości kontroli nad indywiduum. Zawsze znajdujemy się w sytuacji niepewności co do tego, kto jest kim, a wszyscy inni tkwią w tej samej niepewności w stosunku do nas. To, co charakteryzuje społeczeństwo i kulturę człowieka, to skala losowości i przypadku, wyrażona pod pojęciem historyczności układów, w których żyjemy. Ta zasłona niewiedzy jest jedną z najlepszych gwarancji wolności indywidualnej, przynajmniej do czasu, gdy technologia nie przełamie bariery epistemicznej pomiędzy naszym umysłem a systemami kontroli.

\section{Literatura}

Ainslie, G. (2001). Breakdown of Will. Cambridge: Cambridge University Press.

Arendt, H. (1996). Wola, przeł. R. Piłat. Warszawa: Czytelnik.

Ariely, D. (2008). Predictably Irrational - The Hidden Forces that Shape Our Decisions. New York: HarperCollins.

Ashmore, R.D., Jussim, L. (eds.). (1997). Self and Identity: Fundamental Issues. Oxford: Oxford University Press.

Barkow, J.H., Cosmides, L., Tooby, J. (eds.). (1995). The Adapted Mind: Evolutionary Psychology and the Generation of Culture. Oxford: Oxford University Press.

Bergen, B.K. (2017). Latające świnie. Jak umysł tworzy znaczenie, przeł. Z. Lamża. Kraków: Copernicus Center Press.

Bernstein, P. (2020). Przeciw bogom. Niezwykłe dzieje ryzyka. Warszawa: Wydawnictwo Naukowe PWN.

Bicchieri, C. (2002). The Grammar of Society: The Nature and Dynamics of Social Norms. Cambridge: CUP. 
Bickhard, M.H. (2008). „Social Ontology as Convention”. Topoi, 27, s. 139-149.

Brockman, J. (ed.). (2019). Possible Minds: Twenty-Five Ways of Looking at AI. New York: Penguin Press.

Carroll, S.M. (2017). The Big Picture: On the Origins of Life, Meaning, and the Universe Itself. New York: Dutton.

Clark, A. (1997). Being There: Putting Brain, Body, and World Together Again. Cambridge, MA: MIT Press.

Clark, A., Chalmers, D.J. (2008). „Umysł rozszerzony”. W: M. Miłkowski, R. Poczobut (red.). Analityczna metafizyka umystu. Warszawa: Wydawnictwo IFiS PAN.

Colli, G. (1994). Po Nietzschem, przeł. S. Kasprzysiak. Kraków: Wydawnictwo Literackie.

Damasio, A. (2018). The Strange Order of Things: Life, Feeling, and the Making of Cultures. New York: Pantheon Books.

Deacon, T.W. (1998). The Symbolic Species: The Co-evolution of Language and the Brain. New York: W.W. Norton \& Company.

Dennett, D.C. (1983). „Intentional Systems in Cognitive Ethology: The 'Panglossian Paradigm' Defended”. The Behavioral and Brain Sciences, 6, s. 343-390.

Dennett, D.C. (1987). The Intentional Stance. Cambridge, MA: MIT Press.

Dennett, D.C. (1991). Consciousness Explained. Boston, MA: Little Brown.

Dennett, D.C. (1997). Natura umysłów. Warszawa: CiS.

Dennett, D.C. (2003). Freedom Evolves. New York: Viking.

Dennett, D.C. (2008). „Rzeczywiste wzorce”. W: M. Miłkowski, R. Poczobut (red.). Analityczna metafizyka umystu. Warszawa: Wydawnictwo IFiS PAN.

Dennett, D.C. (2014). Darwin's Dangerous Idea: Evolution and the Meaning of Life. New York: Simon \& Schuster.

Dennett, D.C. (2015). Dźwignie wyobraźni i inne narzędzia do myślenia, przeł. Ł. Kurek. Kraków: Copernicus Center Press.

Dennett, D.C. (2017). Od bakterii do Bacha. O ewolucji umysłów, przeł. K. Bielecka, M. Miłkowski. Kraków: Copernicus Center Press.

Dennett, D.C. (2020). „Herding Cats and Free Will Inflation”. Romanell lecture delivered at the one hundred seventeenth annual Central Division meeting of the American Philosophical Association. Proceedings and Addresses of the APA, 94, s. 148-164.

Dennett, D.C., Caruso, G.D. (2021). Just Deserts: Debating Free Will. Cambridge: Polity.

Dolev, Y., Roubach, M. (eds.). (2016). Cosmological and Psychological Time. Cham: Springer.

Dretske, F. (2004). Naturalizowanie umystu, przeł. B. Świątczak. Warszawa: IFiS PAN.

Fodor, J.A. (1994). The Elm and the Expert: Mentalese and Its Semantics. The 1993 Jean Nicod Lectures. Cambridge, MA: MIT Press.

Gamble, C., Gowlett, J., Dunbar, R. (2017). Potęa mózgu. Jak ewolucja życia społecznego kształtowała ludzki umyst, przeł. R. Kosarzycki. Kraków: Copernicus Center Press.

Gigerenzer, G., Todd, P.M., ABC Research Group. (1999). Simple Heuristics That Make Us Smart. Oxford: Oxford University Press.

Gleick, J. (1996). Chaos. Narodziny nowej nauki, przeł. P. Jaśkowski. Poznań: Zysk i S-ka. Gleick, J. (2012). Informacja. Bit, wszechświat, rewolucja. Kraków: Znak.

Godfrey-Smith, P. (2019). Inne umysły. Ośmiornice i prapoczątki świadomości. Kraków: Copernicus Center Press. 
Hacking, I. (1999). The Social Construction of What? Cambridge, MA-London: Harvard University Press.

Haig, D. (2020). From Darwin to Derrida: Selfish Genes, Social Selves, and the Meanings of Life. Cambridge, MA: The MIT Press.

Hammerstein, P. (ed.). (2003). Genetic and Cultural Evolution of Cooperation. Cambridge, MA: The MIT Press.

Haugeland, J. (1981). „Semantic Engines: An Introduction to Mind Design”. W: J. Haugeland (ed.). Mind Design. Cambridge, MA: MIT Press.

Heise, D., MacKinnon, N. (2010). Self, Identity, and Social Institutions. New York: Palgrave Macmillan.

Hetmański, M. (2013). Epistemologia informacji. Kraków: Copernicus Center Press.

Hippel, W. von, Trivers, R. (2011). „The Evolution and Psychology of Self-deception”. Behavioral and Brain Sciences, 34, s. 1-56.

Kahneman, D. (2012). Pułapki myślenia. O myśleniu szybkim i wolnym, przeł. P. Szymczak. Poznań: Media Rodzina.

Kim, J. (2002). Umysł w świecie fizycznym, przeł. R. Poczobut. Warszawa: IFiS PAN.

Kushnir, T., Gopnik, A., Chernyak, N., Seiver, E., Wellman, H.M. (2015). „Developing Intuitions about Free Will between Ages Four and Six”. Cognition, May.

Lakoff, G. (2008). The Political Mind. New York: Viking.

Lakoff, G., Johnson, M. (1999). Philosophy in the Flesh: The Embodied Mind and its Challenge to Western Thought, New York: Basic Books.

Lerner, B.D. (2002). Rules, Magic, and Instrumental Reason: A Critical Interpretation of Peter Winch's Philosophy of the Social Sciences. London-New York: Routledge.

Majchrowicz, B., Doboszewski, J., Placek, T. (2016). „Droga donikąd? Co pozostało z eksperymentów Libeta nad wolną wolą". Filozofia Nauki, rok XXIV, 2(94).

Marcus, G. (2009). Prowizorka w mózgu, przeł. A. Nowak. Sopot: Smak Słowa.

Mayr, E. (1996). „What is a Species, and What is Not?”. Philosophy of Science, 2(63), Jun., s. 262-277.

Mercier, H., Sperber, D. (2011). „Why Do Humans Reason? Arguments for an Argumentative Theory". Behavioral and Brain Sciences, 34, s. 57-111.

Merton, R.K. (1936). „The Unanticipated Consequences of Purposive Social Action”. American Sociological Review, 6(1), Dec., s. 894-904.

Millikan, R. (1984). Language, Thought and Other Biological Categories. Cambridge, MA: MIT Press.

Mokrzycki, E. (red.). (1992). Racjonalność i styl myślenia. Warszawa: IFiS PAN.

Morgan, M.S., Morrison, M. (eds.). (1999). Models as Mediators: Perspectives on Natural and Social Science. Cambridge: Cambridge University Press.

Odrowąż-Sypniewska, J. (2006). Rodzaje naturalne. Rozważania z filozofii języka. Warszawa: Semper.

Platon (1997). Prawa, przeł. M. Maykowska. Warszawa: Alfa.

Ramachandran, V.S. (2012). Neuronauka o podstawach człowieczeństwa. O czym mówi mózg?, przeł. A. i M. Binderowie, E. Józefowicz. Warszawa: WUW.

Richerson, P., Boyd, R. (2006). Not by Genes Alone: How Culture Transformed Human Evolution. Chicago: The University of Chicago Press.

Rosenberg, A. (2008). Philosophy of Social Science, Boulder: Westview Press. 
Schwartz, B. (2020). Paradoks wyboru. Dlaczego więcej oznacza mniej, przeł. M. Walczyński. Warszawa: PWN.

Simmel, G. (1997). Filozofia pieniądza, przeł. A. Przyłębski. Poznań: Humaniora.

Sperber, D. (1996). Explaining Culture: A Approach. Naturalistic. Cambridge: Blackwell Publishers.

Sterelny, K. (2003). Thought in a Hostile World: The Evolution of Human Cognition. Oxford: Wiley-Blackwell.

Tomasello, M. (2009). The Cultural Origins of Human Cognition. Cambridge, MA: Harvard University Press.

Tomasello, M., Carpenter, M., Call, J., Behne, T., Moll, H. (2004). „Understanding and Sharing Intentions: The Origins of Cultural Cognition". Behavioral and Brain Sciences, 28, s. 675-691.

Wegner, D.M. (2002). The Illusion of Conscious Will. Cambridge, MA: MIT Press.

Weinberg, S. (2016). To Explain the World: The Discovery of Modern Science. New York: Harper Perennial.

Woleński, J. (1997). „Informacja i semantyka”. Filozofia Nauki, R. V, 1(17), s. 59-64.

Żyro, T. (2008). Wola polityczna. Warszawa: Wydawnictwa Akademickie i Profesjonalne.

\section{Streszczenie}

Artykuł przedstawia tezę, że decyzja rozumiana jako akt wyboru jest możliwa do wyjaśnienia w ramach teorii kontroli, która przekłada się na rzeczywistą autonomię człowieka. Decyzja w tym ujęciu nie jest typem fenomenu oderwanego od przyczynowej struktury świata ani też rodzajem poręcznej konstrukcji teoretycznej w wyjaśnianiu zachowań, ale funkcjonalnym aspektem umysłu zgodnym (kompatybilnym) z naturalistycznym obrazem świata, obejmującym również humanistykę. W ramach takiej struktury wyjaśniania możemy umieścić decyzję jako element struktur kontroli, które funkcjonują równolegle do struktur przyczynowości i stanowią niezbędny składnik każdego autonomicznego systemu. Co więcej, przy założeniu, że umysł spełnia funkcję semantycznego silnika, możemy zarysować kierunek badań, w ramach którego semantyka (język oraz znaczenia i treści kultury) może być interpretowana jako podstawa wyborów (decyzji) dokonywanych w ramach kontekstu kulturowego.

Słowa kluczowe: naturalizm, decyzje, wolny wybór, racjonalność, determinizm, nauki społeczne 
